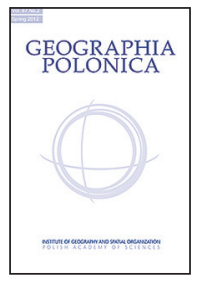

\title{
SOCIAL SEGREGATION AND SPATIAL DIFFERENTIATION OF ELECTORAL ALIGNMENT IN VILNIUS METROPOLITAN AREA
}

\author{
Donatas Burneika • Aušra Baranauskaitè • Rūta Ubarevičienè \\ Lithuanian Social Research Centre \\ Institute of Human Geography and Demography \\ A. Goštauto g. 9, LT-01108 Vilnius : Lithuania \\ e-mails: donatas.geo@gmail.com • baranauskaite.ab@gmail.com • ruta.ubareviciene@gmail.com
}

\begin{abstract}
The paper analyses two interrelated fields: residential differentiation in the Vilnius metropolitan area on the basis of socio-economic status and of political alignment. Data from the 2001 and 2011 censuses were used to investigate socio-economic and ethnic segregation and data from the parliamentary elections of 2000 and 2012 were used for the analysis of political alignment. Indices of segregation and isolation were calculated, and the main occupational groups were used as a proxy for socio-economic status. GIS tools were used to visualise existing spatial differences. Though most indices indicated quite low levels of segregation, the situation was changing. The wealthiest and poorest groups tend to live more and more separately. The political preferences of the different social groups differ and differentiation of political field is increasing. The paper reveals socio-political spatial interrelations in the metropolitan area which have a unique ethnic structure. Our findings suggest that socio-economic structure is a major factor determining the degree of differentiation of electoral alignment in the metropolitan area. The different political preferences of the different ethnic groups could be related not simply to ethnicity but rather to socio-economic status.
\end{abstract}

\section{Key words}

Vilnius $\cdot$ metropolitan area $\cdot$ social segregation - electoral segregation $\bullet$ electoral differentiation - postcommunist city $\bullet$ residential differentiation

\section{Introduction}

The problem of social segregation and its negative outcomes has recently drawn the attention of many scholars in Western Europe, though the phenomenon has been among the most topical themes in various fields of urban studies since the beginning of the 20th century (Hamnett 1996). A recently published study "Socio-economic segregation in European capital cities. East meets West" (Tammaru et al. 2016), where the situation in 15 capital cities in Europe was analysed, describes the trends which have recently been taking 
place in many metropolitan areas in Europe. The majority of authors identify growing social and spatial inequalities, which are mostly related to the neo-liberal economic policies, which dominate in all the countries studied (Tammaru et al. 2016). While the problem of spatial segregation is long lasting in many western cities, it's relatively new in post-communist areas. The policy of the communist regime was directed towards the uniform development of the socio-spatial organisation and although the task wasn't completed, residential differentiation was not a matter for discussion (Szelenyi 1996; Stanilov 2007). Later on, the transition from the Soviet regime to a market-led neo-liberal economy resulted in the current abandonment of public housing policies and the rapid sprawl of metropolitan cities into city-regions mostly through processes of poorly planned and unregulated suburbanisation (Hamilton et al. 2005; Boren, Gentile 2007; Gentile et al. 2012). The abovementioned study illustrates that processes of social segregation are also gaining pace in the Baltic countries. The spatial social differentiation should result in the differentiation of political (electoral) alignment, as political preferences are strongly related to personal wellbeing and other socio-demographic characteristics. The governing of such multi-ethnic socially and politically segregated areas consisting of several municipalities is very complicated as the political power to govern is very fragmented, while a regional level of government does not exist in Lithuania. Bearing in mind that effective spatial planning is one of the tools which could provide some regulation of processes of spatial segregation in society, such fragmentation presents a serious threat to the sustainable spatial development of metropolitan areas - i.e. areas consisting of urban centres of national importance and their suburbs.

This paper presents one of the first attempts to carry out quantitative spatial analysis and to compare processes of socioeconomic segregation and residential differentiation by political alignment in the Vilnius metropolitan area (MA). Special attention is paid to the rapidly sprawling and changing suburban zone.

The main aim of the paper is to explore the interrelationship between socio-economic segregation processes and spatial residential differentiation of political (electoral) alignment in the Vilnius MA in the first decade of the 21 st century. The main research questions are: "What spatial implications does the growing social segregation have on the political landscape of Vilnius MA?" and "What spatially differentiated political landscapes are being created as social segregation increases within cities?" The authors do not try to describe any factors relating to individual political preferences or illustrate changes in the popularity of any political party or coalition. The main hypothesis of the paper is related to the previous findings that there exist close interdependencies between a person's social status and their political preferences, which has been indicated in scientific literature both in Lithuania and elsewhere in the world (Manis \& Stone 1958; Wolfinger \& Rosenstone 1980; Baldassare 1992; Charter of the New... 1996; Sklar 2000; Johnston \& Pattie 2006; Petrulis 2009; Legeby 2010; Savickaite et al. 2013; Baranauskaite et al. 2015; Ubarevičienè et al. 2015). We expect that socio-spatial segregation is increasing and that this should create a more and more differentiated political landscape as social and demographic differences between different parts of the MA increase. Thus the establishment of the spatial character and the degree of differentiation of the electoral landscape is the main task of the research. The revelation of interdependencies between social and political phenomena is a secondary task, though the authors do not try to question the existence of these relations.

The highly differentiated ethnic landscape is a unique feature of Vilnius MA in the context of all CEE countries and this provides an additional influence on the spatial differentiation of political alignment. The ethnic dimension of political alignment and the establishment of interdependencies between the ethnic and political landscapes is not a priority of the study. It is also not directly targeted at the 
establishment of the factors of electoral behaviour. The differentiation of political alignment itself is the main target of the paper, notwithstanding exactly which political parties are causing it. The Lithuanian capital city has the greatest degree of social (and ethnic) residential differentiation; therefore this is where we may expect to find the most visible electoral differentiation.

This paper does not try to discuss the positive or negative sides of the segregation processes in Lithuania. The authors try to raise the problem of the interrelationship of the deepening spatial, social and political differences in metropolitan areas, which tend to form spatially segregated and polarised societies, a trend which potentially could result in growing social, political and in some cases ethnic tensions.

\section{Spatial segregation in post- -communist space: General theory and local knowledge}

The term 'segregation' is used in this paper in accordance with the definition provided in the Dictionary of Human Geography. According to it, "the phenomenon of segregation is said to occur when two or more groups occupy different spaces within the same city" (Hiebert 2009). In that sense it basically corresponds to the concept of socio-spatial residential differentiation. The segregation could be based on groups that differ in any aspect - social, political, cultural, ethnic, or life style preferences (van Kempen \& Șule Özüekren 1998).

Social segregation (mostly its three dimensions - class, race (ethnicity) and household structure) has been among the most topical themes in various fields of urban studies since the beginning of the 20th century, when the famous Chicago school developed (Park et al. 1925; Hamnett 1996). The main theoretical idea of this paper is related to the statement that changing social structure should sooner or later lead to changes in the urban landscape, as increasing social inequalities result in segregation of urban space (Sýkora 2009).
However, the relationships between social and spatial structures are not straightforward and are dependent on many local factors; therefore consequences might vary substantially between cities (Tammaru et al. 2016).

Unsurprisingly, studies investigating the socio-spatial structure of the post-socialist countries of Central and Eastern Europe were very scarce until very recently. It is especially true when talking about Lithuania. First of all, survey-based sociological research on the class structure of society was only carried out at the very end of the 20th century (Masiulis 1997). Later on research commenced on social segregation. Works by Aidukaite (2014), Krupickaitè (2011), Žilys (2013, 2015) and Tereškinas et al. (2013) used the concept of residential segregation when analysing the major Lithuanian cities, but these analyses were based on data from sociological surveys. The previous studies of the authors of this paper (Burneika et al. 2015; Valatka et al. 2016) also revealed that segregation levels, measured using census data, are quite low in Lithuanian MAs, although Vilnius city is changing rapidly as more affluent groups live more and more separately from the others.

Previous studies have indicated that the concentration of some groups of residents in certain areas can not only lead to social segregation, but to political segregation as well. Residents with different political preferences and electoral behaviour also tend to live separately as interdependence exists between residents' socio-economic status and their political preferences (Wolfinger \& Rosenstone 1980; Massey \& Denton 1998; Walks 2006).

Analysis of spatial differentiation of political opinion is, unsurprisingly, new in postSoviet space. Special attention to the suburban zone is also a relatively new trend even in Western Europe. The term 'suburban nature' describes distinctive socio-political communities, which were formed as a result of rapid mass suburbanisation in the USA (Zaninetti 2009). Notwithstanding that suburbanisation is not a new phenomenon, there is still little knowledge about how the social environment impacts on political behaviour in these 
areas (Manis \& Stone 1958; Baldassare 1992; Charter of the New... 1996; Johnston \& Pattie 2006; Oliver \& Ha 2007; Davoudi 2008).

The processes producing sprawl around cities bring new social problems that lead to political tensions. Some researchers (Bilodeau 2006; Oliver \& Ha 2007) have drawn attention to the problem of the adaptation of newcomers. It is stated that newcomers increase the disparities in the political process (Bilodeau 2006). The newcomers come to live in new settlements (suburbs) and they bring with them absolutely different lifestyles, worldview, and political attitudes and preferences to the residents who have already lived for a while in the surrounding (suburban) areas (Oliver \& Ha 2007; Ubarevičienè et al. 2015). Some studies (Massey \& Denton 1998; Robinson \& Noriega 2010; Hall et al. 2010) found that internal migration flows were having a huge effect on the political preferences of residents that produced significant electoral changes throughout a whole region. And the most important thing that was noted was that ethnic imbalances did not play a crucial role - the main factors which led to social and political disparities are socio-economic (Leighley \& Vedlitz 1999; Gimpel et al. 2004).

Residential segregation is not only associated with socio-economic indicators, but also with ethnicity. If the ethnic minority population grows, their spatial isolation from the majority increases (Baldassare 1992; Brade et al. 2009).

Many have hypothesised (Manis \& Stone 1958; Wolfinger \& Rosenstone 1980; Baldassare 1992; Charter of the New... 1996; Sklar 2000; Johnston \& Pattie 2006) that neighbourhoods and social context have an important influence on residents' voting decisions. The electoral participation and preferences of residents are partly related to the contextual effect (Cohen \& Dowson 1993) and this means that the concentration of some groups of residents can lead to social and political isolation. According to Massey and Denton (1998), socially segregated neighbourhoods determine political isolation. Isolation can produce tensions between different social groups. This problem can often be seen in neighbourhoods with high levels of poverty (Massey \& Denton 1998; Gainsborough 2001; Bilodeau 2009). Segregation is strongly related to socio-spatial polarisation and even reinforces economic inequality (Legeby 2010).

British geographers R. Johnston and C. Pattie state that the living environment has an impact on political, economic, and social processes, which results in specific electoral behaviour (Johnston \& Pattie 2006). Newly inhabited areas have distinctive problems related to the political activity of residents, their territorial identities, and representation (Scott 2001). Research carried out in the USA revealed that newcomers (suburbanites) are keen to support central-right wing parties, while residents of city cores prefer centralleft wing ones (Manis \& Stone 1958). Similar trends were noted in Western Europe. Suburban residents support centre-right wing liberal or conservative political parties while the political preferences of the dwellers of the city core differ depending on their socio-demographic characteristics, therefore their votes are more mixed between centre-right (liberal and conservative) and centre-left (social democrat) wing parties (Hirch 1968; Gainsborough 2001; Walks 2005, 2006).

A group of specialists in political science and political geographers (Sellers et al. 2013) carried out a group project on political behaviour in metropolitan areas "The political ecology of the metropolis: metropolitan sources of electoral behaviour in eleven countries" dealing with the new processes of urban regions and how these new territories are shaping the national economy and politics. The authors maintain the hypothesis that city populations have expanded into much broader territories and as a result the votes of suburbanites have drawn a specific landscape of political preferences (which was a result of the changing socio-spatial landscape). These territorial differences in social and electoral features have created territorial unevenness in certain types of metropolitan area. In fact, there are mixed spatial patterns of electoral support for political parties in the metropolitan area. 
This is due to multilevel influences (social, cultural, etc.) - different parts of the metropolitan area have experienced clear divides between different types of metropolitan community (Sellers et al. 2013). Great economic diversity and great territorial disparities between different parts of the metropolitan area create spatial cleavages - spatially differentiated electoral behaviour of different parts of the metropolitan area is very clear among these two opposing social groups. It is also claimed that more affluent suburbs, which are characterised as comparatively more liberal, are less culturally influenced. In other words - the electoral behaviour of communities, which display more features of affluence are much more affected by their socio-economic status than their ethnic origin (Walks 2006). The authors of this research note that this tendency is particularly strongly expressed in post-communist countries. On the other hand, the authors of this research do not reject cultural issues and their effect on electoral support for political parties. They claim that economic and cultural features both modify and reinforce spatially differentiated electoral divisions within metropolitan areas (Sellers et al. 2013).

Studies of the spatial dimensions of electoral behaviour in Lithuanian urban regions are very scarce, though the spatial differentiation of voters' preferences in Vilnius MA has gained attention from Lithuanian scholars (Savickaitè et al. 2013; Ubarevičienè et al. 2015; Baranauskaite et al. 2015). Some interdependencies between voting behaviour and the changing ethnic landscape were established in the Vilnius suburban zone (Ubarevičiene et al. 2015). Sociological research reveals dependence between the socio-demographic features of voters and their political preferences in Lithuania, though they are not as straightforward as in western countries (Gaidys 2004, 2014; Ramonaite et al. 2014). Younger people as well as those with higher incomes and education level also tend to support liberal and conservative parties in Lithuania. Such a population is more common in the bigger urban areas in Lithuania, where support for right wing political parties is usually much stronger than in the remainder of the country. The importance of ethnic status in electoral preferences was monitored in the Vilnius metropolitan area (Petrulis 2009). Typical residents of rural areas have different political preferences and support centre-left wing parties or parties which could hardly be ascribed to certain traditional political wings (Gaidys 2014; Rudokaite 2014). Under such circumstances we could expect that the most intensive encounter between different political forces would take place in suburban areas, where rich urban society is sprawling into poorer rural areas, especially if the ethnic structure of these two fields is different as it is in Vilnius MA. Anyway, the segregation processes changing the distribution of various social groups in metropolitan areas should inevitably result in a reconstruction of its political pattern, though we may expect that changes should be not straightforward as the political preferences of residents are much more flexible than socio-economic status.

\section{Data and methods}

This study presents a spatial quantitative analysis, which is based on 2001 and 2011 census data (provided by Statistics Lithuania) and on the results of the Parliamentary elections in 2000 and 2012 (provided by the Central Electoral Commission of the Republic of Lithuania). Both censuses took place during postcrisis periods of very modest growth; therefore we have two pictures of stagnant development. The labour market was stagnant and out-migration was at its highest point in 2011. This is an important factor when assessing the reliability of the results obtained in this research, and especially making general conclusions about the 10-year period.

The subject of this research is metropolitan areas, instead of cities within their administrative limits. The outer limits of MAs illustrate the edge of suburbanisation processes, and they were determined at the level of LAU 2 regions. Several indicators were taken into account: the change in population between 2001 and 2011, the number of new individual 
houses, and the level of in-migration (number and origin of newcomers in 2010-2011').

The spatial differentiation of political alignment (supporters of different political parties) was based on the data of the Parliamentary elections of 2000 and 2012. These elections took place in the period of time when the censuses took place and this allows us to draw conclusions about the political preferences of residents in voting units with different socio-economic and ethnic composition. A total of 555 territorial voting units were analysed trying to draw a picture of the political (electoral) landscape in the area.

According to many scholars, the most appropriate cleavage between political parties is 'left-centre-right', however the ascription of an exact political party to any of these blocks is somewhat complicated due to different attitudes towards this classification (Jurkynas \& Ramonaite 2005) and to different political traditions in different countries. Our choice of classification of the political parties is based on the results of research on the Lithuanian party system carried out by Lithuanian sociologists and political geographers. The sociological research (Ramonaite 2007) shows significant correlation between voters' sociodemographic characteristics (age, education, employment, income, dwelling place) and their political preferences. This research takes the hypothesis that political preferences are closely linked to voters' social status. As a result, the research divided the socio-political types of voters on the 'left' and 'right' scale. This classification helped to understand the political identity of voters who were divided into different socio-political types and as a result the political parties were grouped into three categories (that are somewhat different from those defined in the usual classification; Ramonaite 2007).

The changing residential structure of metropolitan areas, which is mostly related to the processes producing city sprawl, is best reflected by the change of popularity

\footnotetext{
${ }^{1}$ The census only captures population moves in the last 12 months prior to the census.
}

of centre-right wing political parties (CRWP), which in Lithuania as in other countries were usually supported by an wealthier, urban population (Gainsborough 2001; Walks 2005, 2006). Therefore the most important parties ascribed to the centre-right were chosen: The Homeland Union - Lithuanian Christian Democrats and three parties with similar ideological tendencies -Movement of Liberals of the Republic of Lithuania, The Liberal and Central Union, and the 'Yes' Union. The most popular traditional centre-left wing political party, the Lithuanian Social Democratic Party (SDPL), was distinguished as a separate group. It is the most influential party in Lithuania, but it does not have a clear supporting social group in the country. Non-traditional parties (without clear identification of a traditional political ideology) were distinguished as the third group (Gaidys 2014). These are mostly supported by a more rural, peripheral and less prosperous population. Electoral action of Lithuanian Poles was also included in this group as a party without a clear traditional ideology; however support for this party is also strongly related to the ethnic status of voters. A strong ethnic identity is mostly related to protest behaviour against existing national policy, which assumes an ethnic meaning (Stokes \& Boix 2009). In other words, to stand against the ethnic majority in the political field means to be a 'protest' voter (Chandra 2004). Thereby, non-traditional parties represent the expectations of some specific groups of society (in this case - ethnic minorities), which usually do not have a clear economic ideology (Ramonaite et al. 2014). In the social and political sciences they are called parties of 'protest votes' (Bjørklund 2007; Erlingsson \& Persson 2011), which mostly stress one specific problem important to some groups of voters (voting to demonstrate their dissatisfaction). Earlier studies (Baranauskaite et al. 2015) showed that support for these parties grows with distance from the major urban centres in Lithuania even in those MAs which traditionally were supporting more nationalistic centre-right wing parties. 
In spite of the methodological approach selected in this research, we have to admit that this classification of political parties is not perfect and the actual policies pursued by parties when they gain political power to rule the country do not necessarily coincide with their names; however this classification reflects the differentiation of political alignment and its relations with social factors as well as urban rural division, which are most important when analysing the consequences of urban sprawl.

In order to explore and to compare the processes of social and political segregation in the different housing zones (city core and outer city (or suburbs)) of the MA we used two traditional segregation indices (Index of segregation (IS) and Index of isolation (II)). The standard methodology of calculation was used (see White 1986; Johnston \& Jones 2010; Marcińczak et al. 2015). We use the International Standard Classification of Occupations (ISCO) provided by the International Labour Organisation (2012) as a proxy for social status, because no data on incomes or other direct indicators of the social status of individuals was gathered during the population censuses. We consider data on occupational groups as a rational choice for the socio-spatial analysis at census tract level, although the links between occupational and social status are not necessarily strict. This is, however, the only statistical indicator that is directly linked to the social status (income) of individuals at a census tract level. The classification is widely used in segregation studies in Europe and in particular in CEE countries (Marcińczak et al. 2015; Tammaru et al. 2016). The wage differences between different occupational groups are obvious in Lithuania, though income differences within occupational groups are quite high. We conclude that this indicator can reveal major spatial differences in the concentrations of various social groups in the city and their change over time, but it is not sufficient for the measurement of actual levels of social segregation or its degree. More detailed analysis, probably based on a case study approach, is needed for a better picture.
Cartographical methods have been used for the illustration of the social, ethnic and political (electoral) segregation processes taking place in Vilnius MA. The maps show differences in the concentration of high and low status occupational and ethnic groups at the census tract level in 2011. Due to the shortage of geographical data at the census tract level in 2001, changes of concentration of different groups at level of LAU 2 regions (Seniūnija, an administrative unit of the municipality without self-governing rights consisting of approx. 10-30 thous. residents) were used to illustrate the ongoing trends. Maps of electoral spatial differentiation in the Parliamentary elections of 2000 and 2012 illustrate the differentiation of support for political parties. Trying to eliminate the influence of the nation-wide fluctuations of popularity of certain parties on the exposure of trends of change of intra-urban spatial differentiation, we didn't measure and map the exact voting results but rather deviations from the country average. An electoral area, where a certain party or party group received a similar proportion of votes of all the possible voters as in that found in the whole country, will be indicated as territory of zero value.

\section{Results}

\section{Vilnius metropolitan area - social and ethnic structure}

Lithuania has been one of the countries with the most rapidly declining populations in the world during the last two decades. Even Vilnius city municipality lost $7.6 \%$ of its population in 1996-2012, while the Lithuanian average was 16\% (Statistics Lithuania 2016). On the other hand, the municipalities surrounding the biggest cities were gaining population during 2001-2011. The population in the whole Vilnius metropolitan area, which stretches far beyond Vilnius city municipality, was growing because of intensive suburbanisation, which overcame negative trends in the city core or more distant periphery. In addition, the ongoing suburbanisation redistributes population inside the MA and changes 
the social and ethnic structure in all its districts (Burneika et al. 2014).

The Lithuanian economy has been one of the fastest growing in the EU since 2004; however this growth had very different impacts on the various groups and areas of Lithuania. The GINI index was constantly among the highest in the EU and stood at 35 in 2014 (Eurostat 2015). The gross earnings of managers was 1.3 times higher than that of professionals (also a high status group), and 3.4 times higher than that of unskilled workers in 2010 when the National Labour Force Survey was carried out (Statistics Lithuania 2016). Vilnius MA was also experiencing quite significant transformations in its occupational structure during the first decade of the 21st century. There was an increase in the higher occupational groups (both in absolute numbers and percentage). The number of professionals increased by $50 \%$ and number of managers by almost $40 \%$ in a decade, while the lowest status group of unskilled workers was shrinking slightly and the middle class was stable. This increase is a good indicator of metropolisation (centralisation) processes taking place in the country. Shrinkage of the labour force (employed and unemployed persons) was evident in all the country except Vilnius MA. We may state that a major shift in its occupational structure illustrates the concentration of wealth in this city. Therefore, we can also expect that the processes of segregation should be more intensive here because the richest groups are most mobile and could relocate their place of residence according to their preferences. Hypothetically the changing patterns of the distribution of various groups in Vilnius city should mostly be the result of the preferences and decisions made by this growing group of better off people.

\section{Occupational structure}

The social structure of the population is the most important characteristic when analysing the political preferences of an area (Gaidys 2014); therefore, the occupational structure of the Vilnius MA will be discussed more thoroughly than other social characteristics of the Vilnius MA. We used two indices to explore different aspects of the social segregation of the MA in 2001 and 2011. The index of segregation (IS) (Fig. 1) indicates how evenly occupational groups are distributed across space, and measures what proportion of the members of a selected group should be relocated to make their distribution even. The index actually indicates the evenness of distribution of various groups instead of the actual segregation (spatial separation from others). The index of isolation (II) (Fig. 2) illustrates the actual spatial separation of different groups and shows the probability of meeting a member of the same group in the area analysed. According to Johnston and Jones (2010), II "is a better surrogate for segregation than unevenness". Analysis of the Vilnius city municipality indicated that there is a major spatial divide separating the highest and the lowest status socio-economic groups: managers and professionals on the one side and unskilled workers on the other. Those groups tend to occupy different spaces and concentrate in separate places. All calculations of the indices showed that the highest degree of segregation is common for the most affluent and most disadvantaged groups. Middle class residents are quite evenly distributed across the city (Burneika et al. 2015; Valatka et al. 2016). The figures calculated for all the indices indicate quite low levels of segregation - for most occupational groups they stood below 20 (Fig. 1), especially in the central part of the MA (indices below 20 indicate that segregation is negligible; IS exceeding 30 starts to indicate a high degree of differentiation of a certain group); the most unevenly distributed group was managers and professionals living in suburban areas.

Though the indices illustrate a quite evenly distributed picture in Vilnius MA, trends were somewhat ambiguous in 2001-2011. The IS of the most unevenly distributed more prosperous occupational groups has dropped indicating growing evenness of the distribution of these fast expanding groups. The growth in the number of members of higher status 


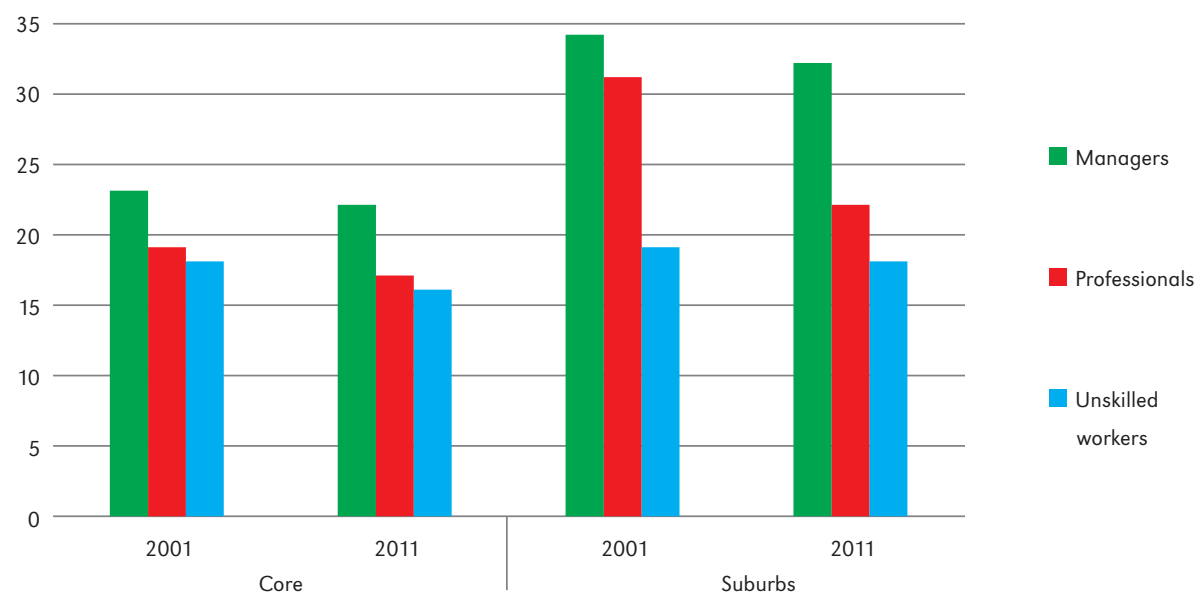

Figure 1. Index of segregation of occupational groups in Vilnius metropolitan area in 2001 and 2011 Source: Census 2001 and 2011.

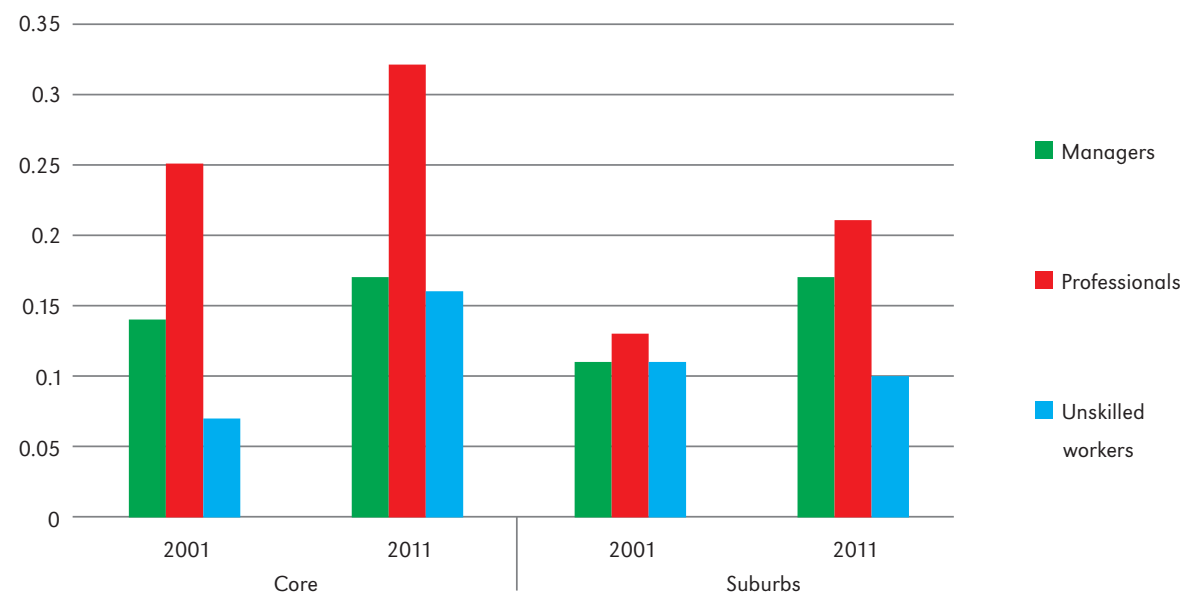

Figure 2. Index of isolation of occupational groups in Vilnius metropolitan area in 2001 and 2011 Source: Census 2001 and 2011.

groups eventually resulted in a more even distribution as the new developments take place in new areas. The index of isolation, an index which measures the actual separation of certain groups from others (i.e. actual segregation), produces a different picture. It is highest in the urban core and it grew considerably in both parts of the MA, especially for richer groups (Fig. 2), which actually confirms the hypothesis that growing social inequalities should result in growing spatial disparities and richer groups should play the most important role.

Though the indices that were measured show quite an even picture, mapping of the phenomena being studied might reveal different trends which could be hidden because of the levelling effects of counteracting processes. Maps were created illustrating the changing concentration of the professional 

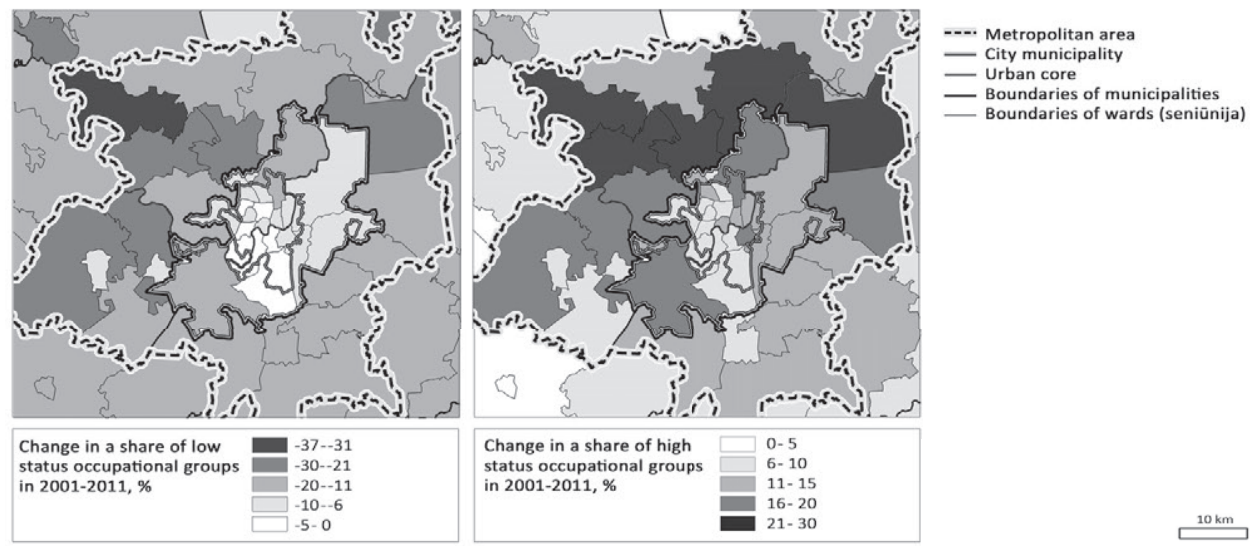

Figure 3. Change in the share of high and low status occupational groups in Vilnius metropolitan area, in 2001-2011

Source: Census 2001, 2011.

groups in the MA at the LAU 2 level (Figs. 3, 4). The distribution of occupational groups in 2011 is shown at the lowest possible level - census tracts.

The changing distribution of the most prosperous occupational groups (managers and professionals are analysed as a single group based on previous findings that showed similar trends in their segregation) clearly correlates with the more general trends seen in the urban sprawl. This confirms previous findings that note that it is the wealthier households that are relocating themselves in the suburbanisation process. Although, the proportion of high status groups grew in all LAU 2 regions, the pace of that growth was very varied. The biggest increase was evident in the Northern suburban areas. The Soviet-built urban complexes, especially those near the big industrial zones, became relatively less prosperous - the proportion of managers there increased by only 5-10 percentage points, which is well below the average. The greatest increase in the proportion of high status residents has been found outside the municipal borders, though this growth was only concentrated in some, mostly northern, directions. These are the most expensive districts, located closest to the city, and therefore attracting the wealthiest households. An increase of residents belonging to the highest status groups was less evident in the more distant areas of the MA and outside it, where the population size was decreasing.

The decrease of lower status groups (service workers, craft workers, machine operators and unskilled workers are usually qualified as a less skilled and lower paid workforce (Marcińczak et al. 2015)) has quite a similar spatial character though the picture is more varied (Fig. 3). Generally we may state that the social status of the closest suburbs is radically changing as relatively poor areas become rich. The situation in the urban core (especially the monofunctional Soviet housing estate zone) is stable, which makes these areas relatively poorer in the MA context.

The following maps (Fig. 4) illustrate the concentration of different occupational groups at the census tract level in 2011. Significant spatial residential differentiation exists, notwithstanding that the indices measured (especially IS) did not reveal it (partly due to the imperfect nature of the indicators used, partly due to the levelling effects of different processes in different areas). In this case, visual analysis of maps of the phenomena is a more suitable tool for revealing the actual picture, or more precisely the existing spatial differentiation of residential areas, than statistical 

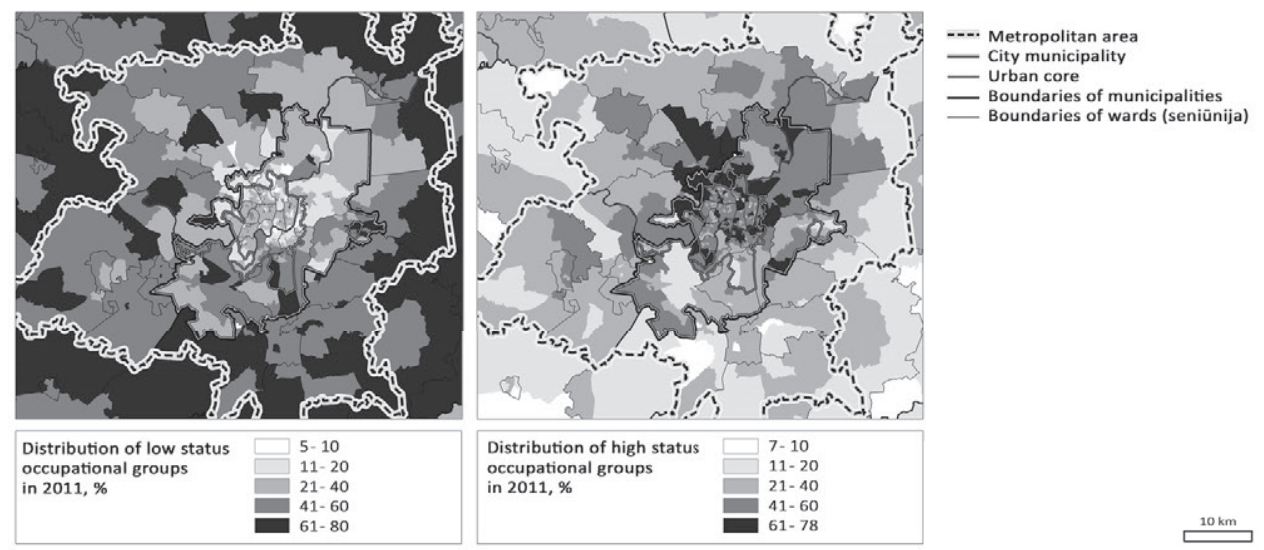

Figure 4. Concentration of high and low status occupational groups in census tracts in Vilnius metropolitan area in 2011

Source: Census 2011.

analysis based on index measurements, which is more useful in cases when mapping is impossible (as in the case of the census tracts of 2001).

The share of high status residents exceeded $2 / 3$ or even $3 / 4$ of all the labour force in some neighbourhoods (Fig. 4), predominantly in the suburban areas on the outskirts of the city municipality. On the other hand, there existed some neighbourhoods where high status groups composed less than 20\% of the population (mainly Soviet housing estate areas, located near the big industrial zones). In general, the areas located to the north of the city are relatively richer and the southern parts are poorer; this is in line with the findings of previous studies demonstrating a major divide between north and south (Valatka et al. 2016).

The distribution of low status occupational groups is somehow opposite to the one of the richest groups but the two distributions are not perfect inversions of each other (Fig. 4). Southern industrial districts were the areas with a higher concentration of less skilled workers. The most peripheral parts of the MA and the settlements outside its limits also had a higher concentration of lower status groups; those are traditionally poorer rural areas with a minimal influence of suburbanisation. Some 'islands' of poorer neighbourhoods could be found even in otherwise rich areas, and it is often related to former satellite industrial towns or rural settlements, which are now surrounded by new developments.

A small micro scale (census tract level) segregation is not perceived as a serious problem, because it does not create larger 'seas' of poverty and consequently does not do critical damage to the urban social environment; macro level trends, on the other hand, should draw attention, because they could result in the formation of large areas of deprivation with all the negative social consequences common in many Western cities.

\section{Ethnic landscape}

The analysis of the interrelations between socially and politically determined residential differentiation would not be reliable without discussing the ethnic situation in Vilnius MA. Social status and ethnicity could have an influence on the voting results as ethnic minorities have their own political parties in Lithuania. Ethnic differences are huge and it can have significant political repercussions. The present ethnic landscape of Vilnius city is a result of historical events in the XX century. The population of Vilnius City more 
than halved during and just after the Second World War when the Holocaust reduced the Jewish population from 57,000 to 2,000 (Jews comprised $30-50 \%$ of the total population at various points in time since the 15th century) (Mendelsohn 1983; Vaitekūnas 2006). Polish repatriation took place right after the War. 107,000 Poles (the majority of the city population before WWII) left the city during 1945-1947 (Czerniakiewicz \& Czerniakiewicz 2007; Daukšas 2008). Repatriation from the surrounding region was of much lesser extent (Eberhardt 2011). These events had an impact not only on the ethnic structure of the population, but also on the social structure of the Polish community as the most educated and
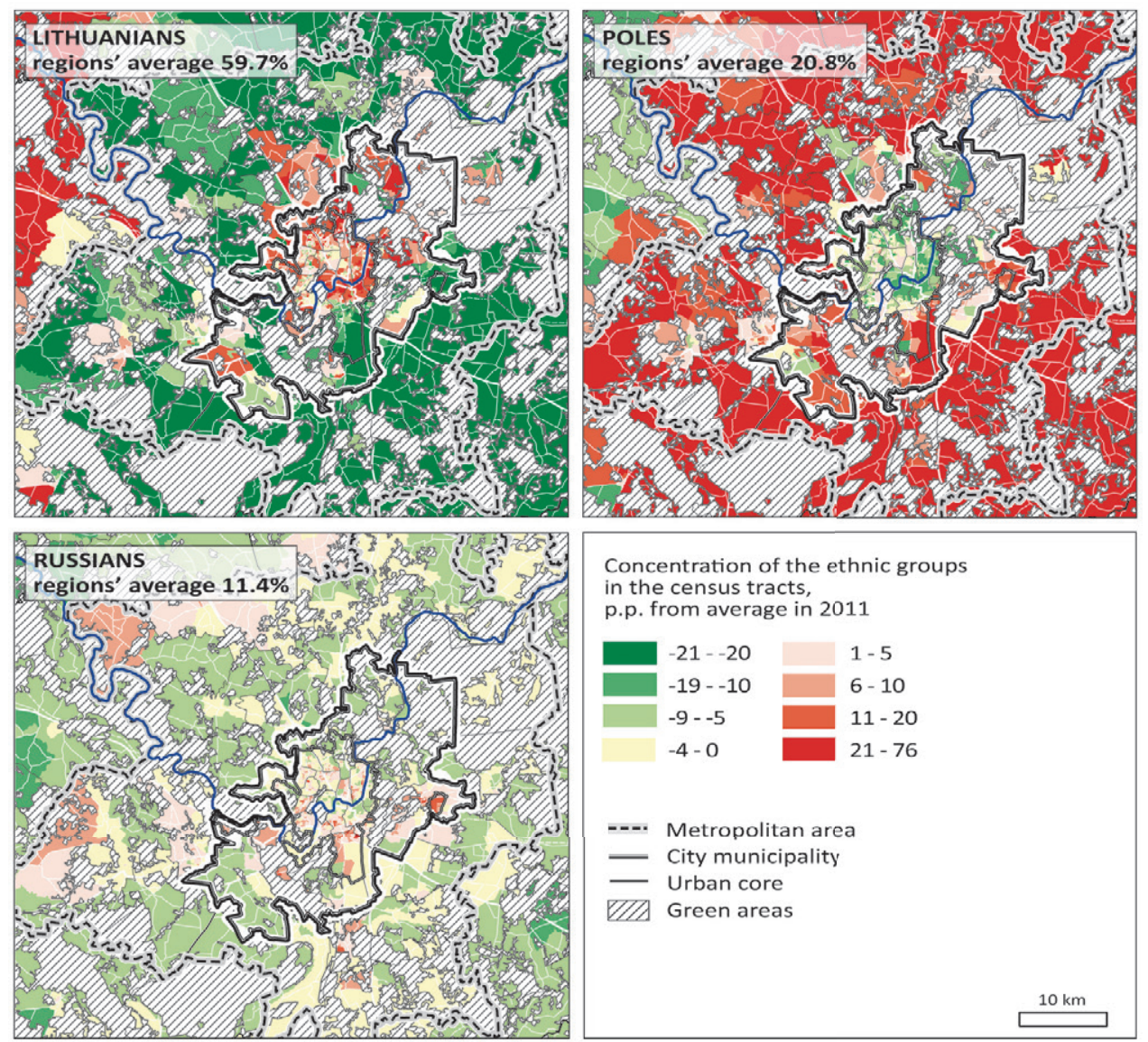

Concentration of the ethnic groups in the census tracts,

p.p. from average in 2011
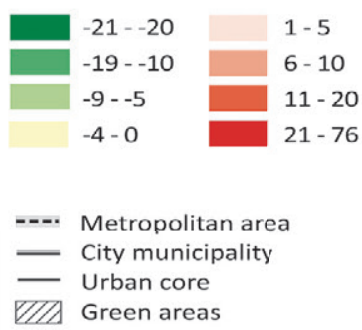

---. Metropolitan area

- City municipality

UIIJ Green areas of rural origin).

richest people had little chance to stay in the country during the Stalin regime. As a conexpansion of the administrative city limits took place in areas dominated by the rural Polish population. Mass industriin the Soviet era. Vilnius City was filled up with immigrants who mostly came from other parts of Lithuania, but also from more remote areas of the Soviet Union. Eventually, a unique ethnic landscape was created in Vilnius MA, with the core city dominated by newcomers from Lithuania and the whole of the USSR, and the surrounding region dominated by Poles (mostly 
One more period of change started after the restoration of Lithuanian independence in 1990. Like in the case of many other postSoviet cities, a proportion of the Russianspeaking residents left Vilnius (Tammaru $\&$ Kulu 2003). The beginning of suburban development, which was constrained under the communist regime, led to processes of city sprawl, which has also started to affect the ethnic composition of Vilnius MA (Fig. 5). Suburbanisation and urban sprawl are changing the ethnic structure very rapidly in areas right next to the city core, where the Polish population used to dominate forming up to $80 \%$ of the population until 1990. The relations between ethnicity and political preferences are clear in Lithuania, where Electoral Action of Poles in Lithuania (EAPL) has their representatives in the national parliament (Gaidys 2014; Ubarevičiene et al. 2015), though we hypothesise that these preferences are not necessarily solely based on ethnic, but also on social, factors. This drives less educated, older and, most importantly, less prosperous rural residents of the urban periphery to choose alternative parties in all the metropolitan areas of Lithuania, even in mono-ethnic urban regions. Ethnic factors determine the domination of this specific party in Vilnius MA, but the "alternative" choices of voters would dominate in the periphery of the region, even if the EALP did not exist. This hypothesis is a generalisation and this is not necessarily true in all individual cases.

Though the ethnic landscape of Vilnius is spatially polarised as Lithuanians constitute the majority of the population in all 21 of Vilnius LAU 2 regions and Poles dominate in more distant suburban areas, the actual picture is very mixed (Fig. 5). Neighbourhoods where Lithuanians constitute less than 20\% of the population exist in Vilnius city municipality however there are neighbourhoods where Lithuanians constitute up to $90 \%$ of population in Vilnius district municipality. We also see clear differences in the concentration of all three ethnic groups in the city (Fig. 5), as more southern areas are dominated by a Slav population and central-northern parts are overrepresented by Lithuanians. The areas surrounding Vilnius city are dominated by residents who consider themselves Poles, while those who move into the suburban area are mainly Lithuanians. In our case, it is a most important fact that a clear resemblance exists between the distribution of different social and ethnic groups as Lithuanians are overrepresented in areas where the more affluent groups concentrate and vice versa. This means that the social and ethnic dimensions of the political alignments are actually interrelated and could reinforce one another.

\section{Quantitative analysis of electoral segregation in Vilnius MA}

The analysis of the socio-demographic and socio-economic characteristics of Vilnius MA has shown that it is a territory with existing and growing spatial differentiation of residents on the basis of these characteristics. This raises the question of changes in the electoral structure of the area being analysed. Hypothetically such a social spatial fragmentation should result in a spatially fragmented electoral structure of the MA. Theories of political behaviour (Parsons 2001) and a number of studies (Huckfeldt 1979; Huckfeldt \& Sprague 1995; Leighley \& Vedlitz 1999; Gimpel et al. 2004; Stein et al. 2005; Bilodeau 2009) have explored the postulate that residential differentiation results in significant changes in residents' electoral behaviour.

Liberal and moderately conservative political parties in Lithuania are usually supported by those residents that have higher education, higher-income, and are younger and politically active (Gaidys 2014). Such a composition of residents is more characteristic of Lithuania's major cities including Vilnius. Thus, the change in the composition of residents due to the process of city sprawl should be best reflected by changes in the popularity of the parties considered to be centre-right. Correlation analysis which had previously been carried out by the authors of the paper (Burneika et al. 2017) proved that interrelations between socio-demographic, socio-economic, 
and ethnic indicators and the political preferences of the residents of Vilnius MA were statistically significant in 2012. The higher the share of the population with such characteristics in an electoral district, the higher was the support for centre-right wing parties. Although the correlation analysis did not include the Polish minority, the cartographic analysis allows us to form the conclusion that the residents belonging to the Polish minority tend to give their political preferences to EAPL. Moreover, a statistically significant correlation was identified between unskilled workers and their political preferences for EAPL (Burneika et al. 2017) which allows us to confirm previous research results that ethnic minorities in Vilnius MA have a much lower probability of having higher education and a well-paid occupation in the labour market. Lithuanians of lower social status mostly tend to vote for other nontraditional parties (generally the Labour Party and Order and Justice) (Ramonaitè et al. 2014; Baranauskaite 2015). Although the correlation was established, the spatial segregation of groups of population with different levels of political preferences remained hidden. The segregation trends of occupational groups were measured using segregation and isolation indexes; therefore the same indices were used for measuring the spatial differentiation of residents with different political preferences (Figs. 6, 7). We must note that in this case the electoral districts analysed are several times bigger than census tracts and therefore potentially could hold a more mixed population structure as the social segregation of a city often has quite a fine grain character.

The process of city sprawl has changed previously semi-rural north-western, northern and north-eastern areas close to the city core, but more distant areas still mostly maintain their older social and ethnic structure. As a result IS illustrates a much higher level of unevenness of political alignment in the suburbs than in the city core. The IS values of RWP and EAPL supporters show the highest degrees of unevenness of distribution of these two groups, especially in suburban areas. The urban core showed a very small and stable degree of unevenness of political alignment as the degree of social and ethnic differentiation there is much smaller. This also confirms the hypothesis that suburbs are the most fragmented and spatially polarised areas in the sense of the electoral structure of the population.

The supporters of SDPL are quite evenly dispersed throughout all the Vilnius MA. Similarly quite a low degree of unevenness is common for the distribution of supporters of all nontraditional parties.

The index of isolation (II) is a better measure by which to determine if members from different groups live in the same area. It illustrates the actual separation of different groups or, in other words, the actual segregation (Johnston \& Jones 2010; Valatka et al. 2016). This index produces quite different results from those using IS (Fig. 7).

The supporters of SDPL are still the least segregated, which confirms the statement that voters from various social groups support this party. The degree of segregation of centreright wing (CRWP) supporters is much greater, though it also does not reach extreme values. It had the biggest support in the urban core during the elections of 2000 . The II of residents supporting CRWP decreased there in 2012 and this may be explained by the processes of gentrification, as more affluent groups spread in previously poor central areas. On the contrary, the segregation of these voters increased in suburbs as suburban settlements grew in new, previously uninhabited areas. The segregation level of residents of EALP is quite low even in the suburbs, which indicates that they live close to supporters of other parties, though the Russian and Polish minorities, whom EAPL represented during the elections concerned, constitute the absolute majority of the population in some more distant areas. On the other hand, rising values of II of CRWP, and especially EAPL, in the suburbs during the 2012 election indicate growing differences between the closest suburbs with a new socio-demographic structure and more distant areas where an older and less prosperous (in the sense of occupation) Polish 
population dominates. The results of the 2012 election demonstrate a much greater segregation of EAPL supporters in the suburbs than in the urban core. The increase of II of those supporting EAPL shows a trend of growing segregation of the ethnic group. Such a situation could raise political tensions in an area with increasing differences, while the pattern of political alignment fragments.

The most extreme rise in the II value is common among the supporters of non-traditional parties when they are considered as a group (including EAPL). This was monitored in all parts of the city but especially in the suburbs

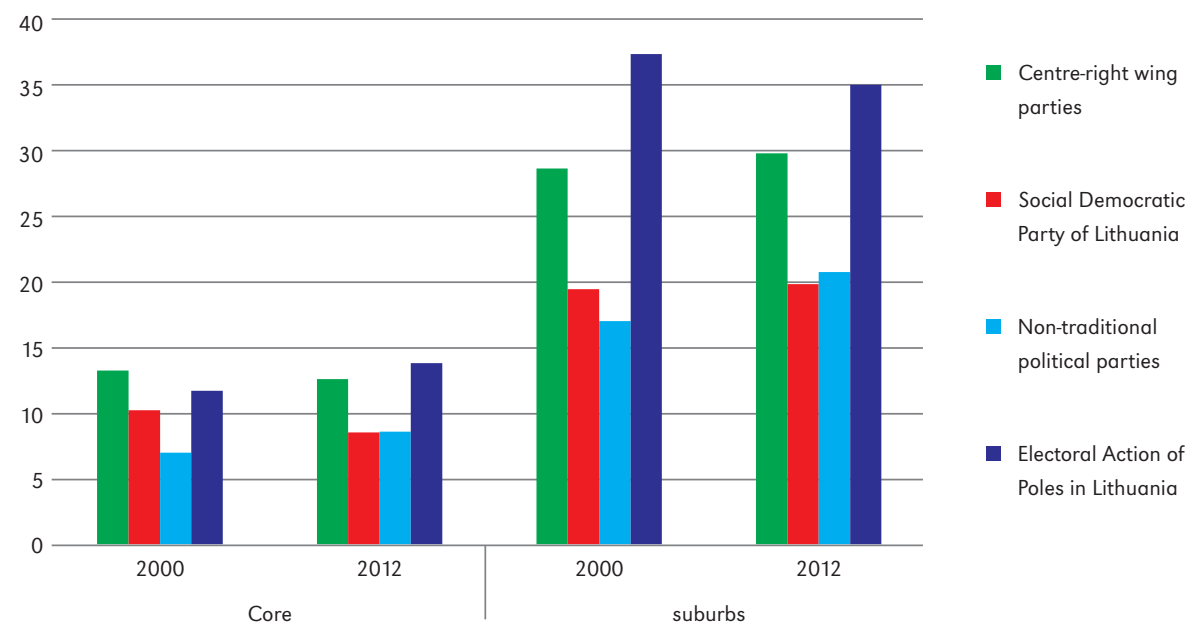

Figure 6. Index of segregation of supporters of different political party groups in Vilnius metropolitan area in 2000 and 2012

Source: Parliamentary elections 2000, 2012.

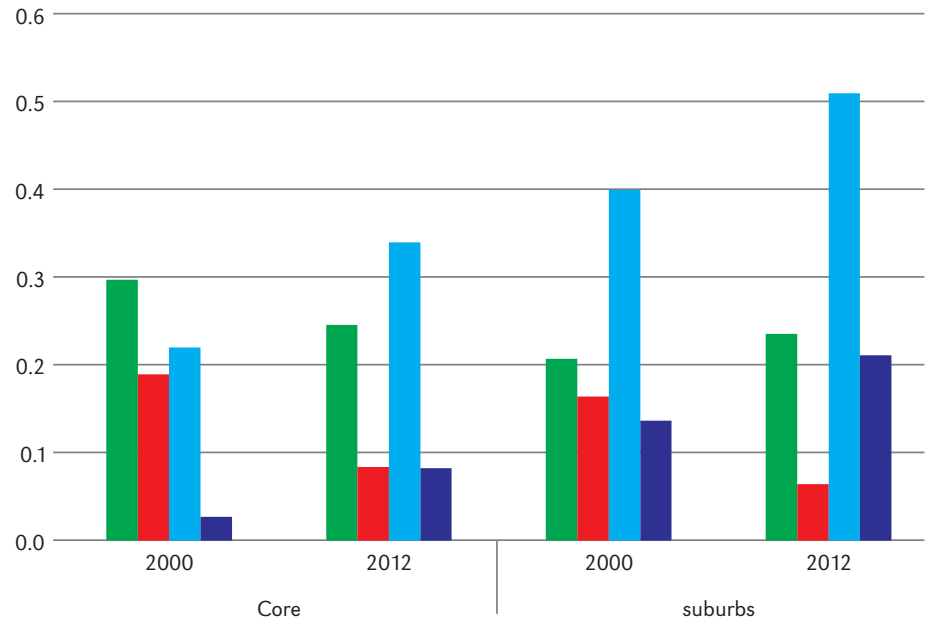

- Centre-right wing parties

Social Democratic Party of Lithuania

- Non-traditional political parties

Electoral Action of Poles in Lithuania

Figure 7. Index of isolation of supporters of different political party groups in Vilnius metropolitan area in 2000 and 2012

Source: Parliamentary elections 2000, 2012. 
where II reached 0.5 in 2012. Voters supporting alternative parties live the most separately from the remaining population but obviously supporters of EALP and those who are voting for other non-traditional parties tend to live in the same voting districts. This finding is in line with previous results indicating that the most numerous ethnic minorities live in the same areas as those belonging to lower status occupation groups (Fig. 4 and 5). Such a high level of II permits us to state that there is a high probability that measurement of segregation based on occupational status tends to hide existing differentiation, and that actual spatial divisions based on real social status in the city should be higher. This also illustrates the high level of differentiation of political alignment in Vilnius MA and this differentiation is based not on a traditional left - right division. Socially less affluent groups do not support SDPL, the traditional left-wing party, but choose alternatives. The interrelationship between ethnic and social segregation reinforces such a polarisation because the distinctiveness of both social and ethnic status could potentially drive residents to choose non-traditional parties.

We may assume that the changing distribution of centre-right wing supporters and more affluent and mobile residents who leave less prosperous areas and concentrate in better places, is the most important process causing a growing degree of social, ethnic and political segregation in the Vilnius urban region. There was an increase in areas where less affluent residents were not attracting affluent residents to a visible extent and where relative spatial differences became more marked.

\section{The geography of residential differentiation of electoral alignment in Vilnius MA}

Quantitative analysis revealed that spatial differentiation of the population according to their political preferences is quite high. In some cases it is even higher than occupational segregation. These findings are in line with previous results, but in order to have a clear and more detailed picture of the changing political alignment of Vilnius MA, we need to employ cartographic analysis. The main goal of the analysis is not to demonstrate the changing popularity of any party or group. We concentrate on demonstrating changes of spatial differentiation of electoral alignment - its degree and character.

Capital city residents with well-paid jobs tend to have right wing political priorities compare to less affluent population groups, especially in more distant less urbanised areas. Consequently those areas where higher social status residents tend to concentrate (Fig. 4) have a much higher share of votes for centre-right political parties (Fig. 8).

Maps of the results of the 2012 Parliamentary election illustrate that significant internal electoral disparities have arisen in the Vilnius MA. Relative support for CRWP increased substantially in suburban areas located close to the city core, especially in northern locations, while it remains the same in more distant eastern parts of the MA outside Vilnius municipality. The spatial differentiation in political alignment is apparently deepening here. While suburbanisation increases relative support for CRWP in the suburban zone and gentrification in the city centre, it remains stable in areas in which the social structure is stable (mostly Soviet housing estates and the most peripheral parts of the region analysed). In general, we may conclude that mapping of the changes of support for CRWP shows a rapid spatial differentiation of political alignment in Vilnius MA as electoral preferences became extremely different in different parts of the MA.

The processes of suburbanisation are obviously playing the most important role in the changes being monitored. The majority of the population, which more actively supports CRWP in those areas are Lithuanians by nationality and have higher education and better jobs. Voting for CRWP in suburban areas was still quite passive in 2000 (Fig. 8) because the suburbanisation process was in its initial stages and had not made any significant changes in the composition of the residents at that time. 

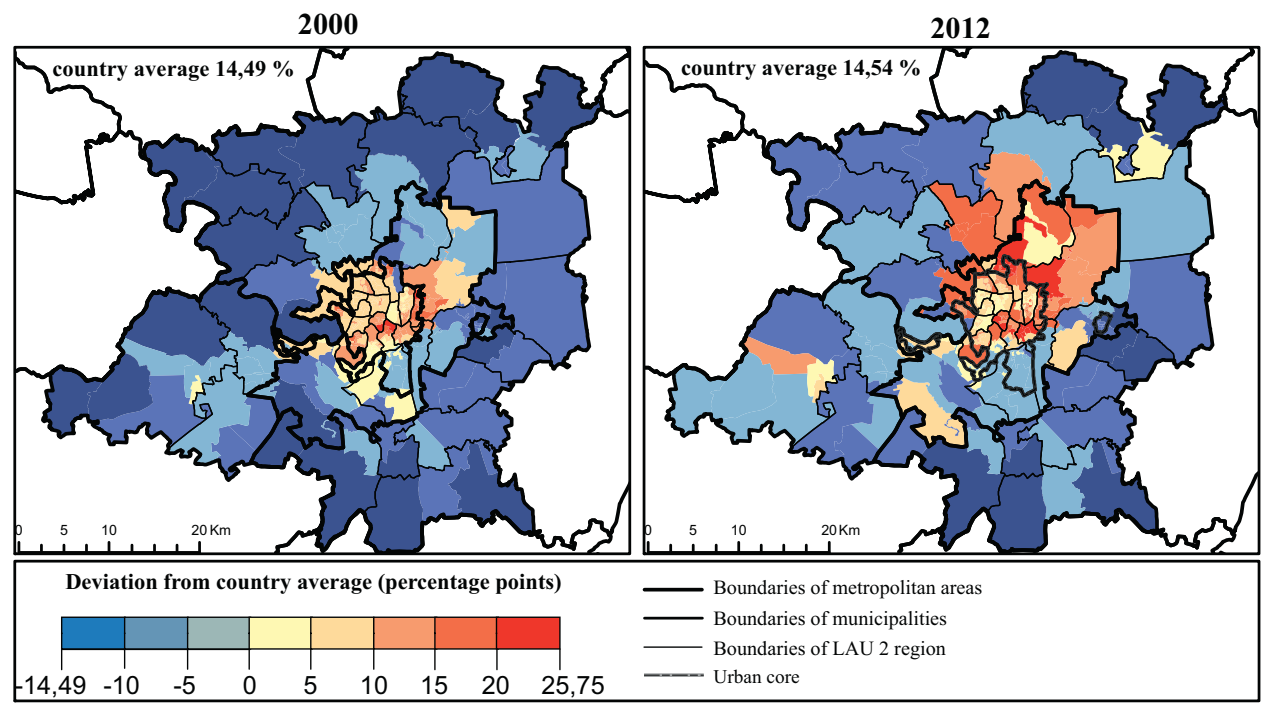

Data: Central Electoral Commission of the Republic of Lithuania

Figure 8. The spatial differentiation of the share of voters supporting centre-right wing political parties (CRWP) in Vilnius metropolitan area in 2000 and 2012

Source: Parliamentary elections 2000, 2012.

Those areas present the most typical examples of the city's urban sprawl as these previously rural territories became part of Vilnius MA. The interrelations between the suburbanisation processes and the territorial distribution of the election results are more than obvious. The causes of the comparatively small popularity of centre-right parties in more distant areas of the Vilnius MA are quite clear - a poorer, less educated, non-Lithuanian population constitutes a much bigger proportion of the population here, so alternative parties remain more popular. Similar trends are common to residents of the more distant and poorer parts of cities in many democratic countries (Kaufmann 2004) or in other Lithuanian metropolitan areas.

The most influential centre-left wing party in Lithuania in 2012, SDPL, is not very popular in Vilnius MA. Nation-wide rural-urban or coreperiphery divisions play a more influential role here, divisions which are more important than differences of socio-economic status or ethnicity. The support for SDPL was relatively weak and quite evenly distributed in Vilnius MA in 2000. Its relative popularity slightly increased but spatial differences almost completely disappeared in 2012 (Fig. 9) (Central Electoral... 2016). We may also assume that some potential supporters of this party in the MA are non-Lithuanian by nationality and therefore vote for EAPL instead, so reducing the general popularity of SDPL. The correlation between the distribution of SDPL supporters and the distribution of socio-demographic or ethnic groups is minimal, though relatively smaller support for the party in more distant areas confirms this latter hypothesis. We may also conclude that the SDPL plays a role in diminishing the spatial polarisation and differentiation of electoral alignment in Vilnius.

Electoral Action of Poles in Lithuania, representing the Polish and Russian speaking population, plays a significant role in the political arena in all south-east Lithuania (Ubarevičienè et al. 2015). Therefore special attention is paid to the voting results of this party when analysing support for all the nontraditional parties (NTP) (Ramonaite 2007). NTP gains support in all Lithuanian urban regions and Vilnius is no exception. On the other hand, the majority of NTP votes went 


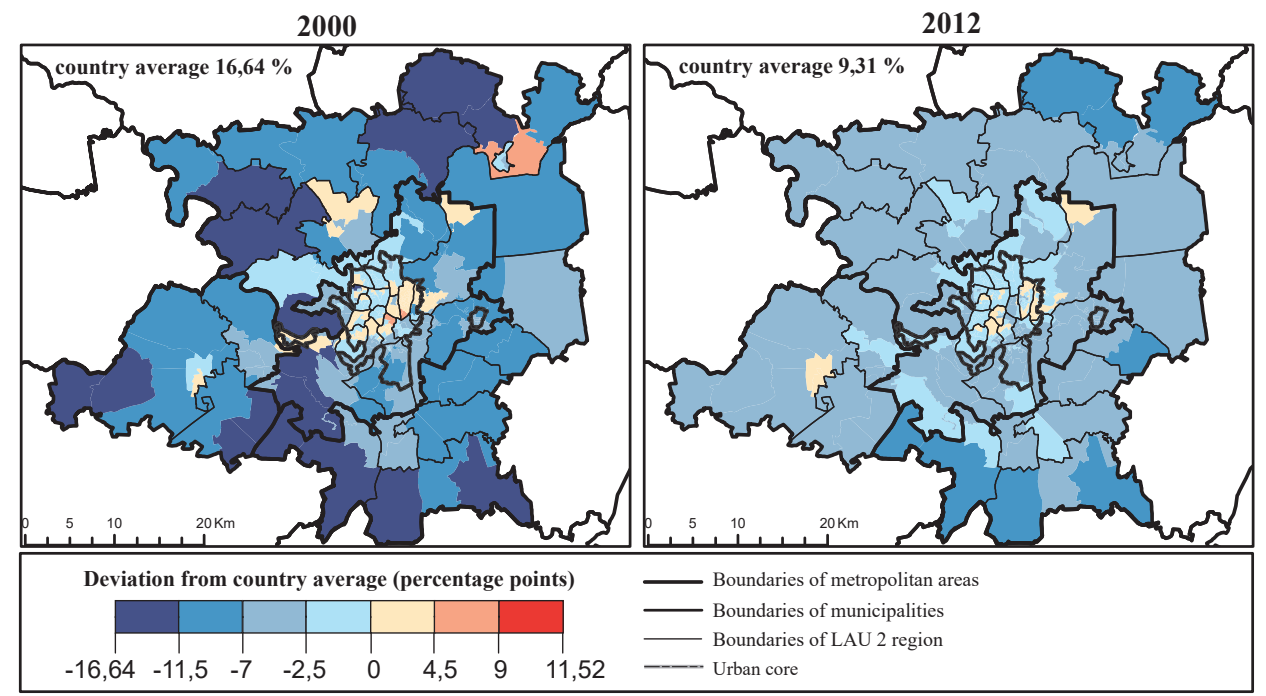

Data: Central Electoral Commission of the Republic of Lithuania

Figure 9. The spatial differentiation of the share of voters supporting the Social Democratic Party of Lithuania (SDPL) in the Vilnius metropolitan area in 2000 and 2012

Source: Parliamentary elections 2000, 2012.

to EAPL in the case of Vilnius. The elections of 2012 clearly indicated that support for NTP has similar spatial characteristics in all the three major metropolitan areas of Lithuania (Baranauskaite et al. 2015), notwithstanding their completely different ethnic structures. The support for CRWP reaches its maximum in the zone of intense suburbanisation (Fig. 8), while the support for NTP is highest in areas outside these zones, where a rural and older population with lower skilled occupations forms a higher proportion of the total population (Fig. 10). Because of this similarity, we may hypothesise that support for EAPL in Vilnius MA is also a result of the social structure, and not simply the ethnic structure, of the population of Vilnius MA. In other words, even if political parties representing political minorities hadn't existed, the differentiation of political alignment would be quite similar as huge spatial socio-cultural differences are common in the MA. The maps show the support for NTP in the MA and it also corresponds to the distribution of supporters for EAPL, though the spatial differentiation in latter case is smaller.
Notwithstanding the significant influence of socio-economic factors on the political landscape in Vilnius MA, the ethnic dimension is also very important (as in all the south-eastern part of Lithuania). Wolfinger (1965) noted that ethnicity may also play a significant role in politics and has a huge influence on voting behaviour. On the other hand, other ethnic minorities, in addition to Lithuanians, who do not have higher education and do not belong to the managerial or professional groups mostly also vote for non-traditional or centreleft political parties (generally the Labour Party or Order and Justice Party) (Ramonaite et al. 2014; Baranauskaite 2015).

The distribution of support for NTP in the 2000 and 2012 elections differs between the city core, and the close and distant suburbs. Support for NTP was much more pronounced in the 2000 elections, when even central areas of the city supported these parties more than the national average (except some of the wealthiest suburbs and very central areas) primarily because of support for EAPL (approx. 1/3 of voters in Vilnius municipality are of Polish and Russian ethnicity). However the 
situation in 2012 had changed substantially as well as its degree of spatial differentiation. It is hard to reliably evaluate the actual factors producing the changes in the general popularity of EAPL in this multiethnic MA because of its changing behaviour towards the representation of the Russian population, which constitutes a large proportion of the population of Vilnius city (general support due to this factor should have increased in areas where Russians constitute a considerable share of the population - namely in the housing estate areas, especially in the industrial southern locations. The substantial relative increase of popularity of EALP in the most distant Northwestern LAU 2 region Dukstai, where Russians constitute approx. 20\% of the population, supports this hypothesis). The analysis of maps (Fig. 10) actually shows that support increased in city core areas but it is still weakly spatially differentiated in the city municipality. It actually increased more in those areas where the concentration of Russians and less affluent groups was examined (South-eastern and southern areas of the city municipality).

A relative decrease of support for all NTP was monitored in most areas of the MA
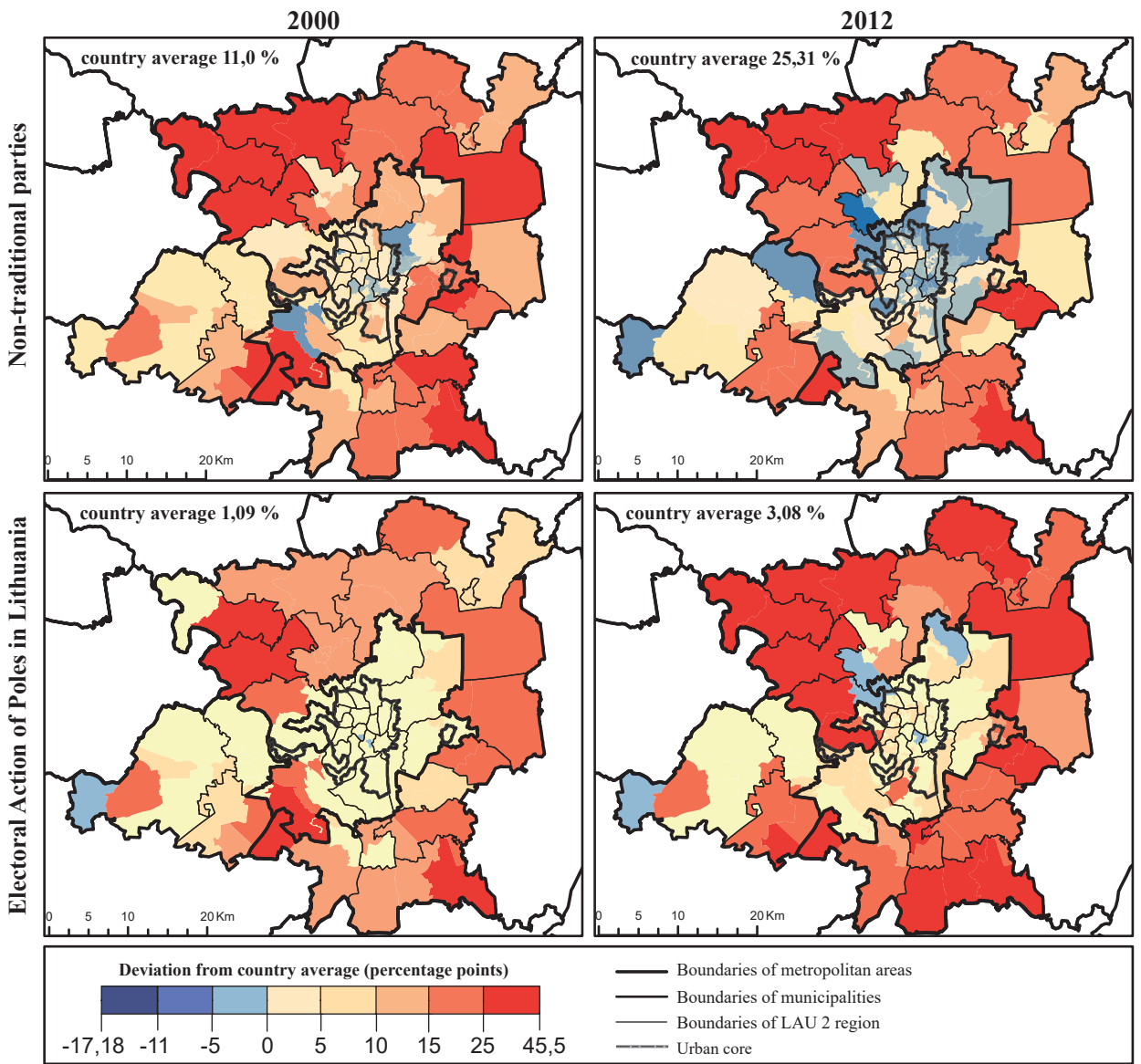

Data: Central Electoral Commission of the Republic of Lithuania

Figure 10. The spatial differentiation of the share of voters supporting non-traditional parties (NTP) and Electoral Action of Poles in Lithuania (EAPL) in Vilnius metropolitan area in 2000 and 2012

Source: Parliamentary elections 2000, 2012. 
(Central Electoral... 2016), with the abovementioned exception of distant areas and mono-functional Soviet housing estate districts. This increased the polarisation of the political alignment in the region. The population of the Vilnius city core started to support CRWP (Fig. 8) more actively (especially in the city centre), though the ethnic structure in city core areas was almost stable. In other words, we may hypothesise that some voters started to vote according to their social (urban) status instead of their ethnicity. At the same time an increase in support for EALP in less affluent areas with a high share of Russian population may illustrate an increasing role of ethnicity in the electoral preferences of non Polish ethnic minorities. The other factor which could have influenced such trends could be related to possible differences in the changes in participation rates between different ethnic groups (i.e. affluent Lithuanians have started to participate more actively and other ethnic groups less actively), but we have not monitored the essential differences in the changes in participation rates in voting areas with a mono-ethnic structure. The participation rates substantially increased in areas of rapid suburbanisation, outside the city core. However we can conclude that the ethnic structure of voting areas inside Vilnius city was having a significantly smaller influence on its electoral structure than it did on those areas outside it. The pattern of ethnic structure in Vilnius city (Fig 5.) is weakly reflected in the voting results, though the situation in the whole MA outside the city municipality is different. In other words, political alignment in Vilnius MA would basically remain similarly differentiated if Electoral Action of Poles in Lithuania didn't exist as the social differences between the ethnic groups in Vilnius MA are large (Burneika et al. 2017).

\section{Conclusions and discussion}

The rapid sprawl of Vilnius city into other municipalities radically changes whole sociodemographic landscape of south-eastern Lithuania. The redistribution of population and resulting spatial residential differentiation are inevitable consequences of those weakly regulated processes. Major socio-spatial divisions in Vilnius MA tended to increase in the first decade of the 21st century, but the processes monitored were highly polarised. Rapid expansion of the most prosperous groups is not changing the urban space evenly and some areas remain stagnant, while the social structure of other areas changes radically. Social changes are followed by a changing ethnic structure. Differences inside the city and between the city and periphery increase. All these transformations change the electoral structure of the MA.

The established interrelationship between the electoral behaviour and the socio-economic status of residents is in line with the results of previous studies (Leighley \& Vedlitz 1999; Gimpel et al. 2004; Gaidys 2014). Our results indicate a strong relationship between ethnicity and political preferences, but as some previous findings (Hirch 1968; Gainsborough 2001; Walks 2005, 2006) indicate, this relationship could also be rooted in the huge social imbalances between the ethnic groups in Vilnius. Therefore though the particular spatial division of political alignment is greatly influenced by the ethnic structure of the MA, the character of its spatial differentiation is determined by social factors. On the other hand, the interrelationship of ethnic and social factors hypothetically increases the degree of this differentiation.

A spatially differentiated process of suburbanisation formed the specific social and ethnic structure of Vilnius MA which displays a high and growing degree of spatial polarisation. We can conclude that residents with common socio-demographic and socio-economic characteristics have rather similar political preferences and patterns of electoral behaviour, therefore the political (electoral) structure of Vilnius MA is also becoming highly spatially polarised.

The degree of electoral spatial differentiation established using the Index of Isolation and visual analysis of the mapped data is even higher than the degree of social segregation, 
measured using data on occupational structure. We may hypothesise that actual social spatial segregation is substantially higher than that shown by the data collected.

Differences between Vilnius metropolitan area and the rest of Lithuania show a growing conflict between centre and periphery (in socio-demographic, socio-economic and political terms). Vilnius is becoming an urban region, where 'protest voters' are less influential than in other regions, which may indicate some political maturity of voters, while the majority of more peripheral residents still don't have

\section{References}

AIDUKAITÉ J., 2014. Housing policy regime in Lithuania: Towards liberalization and marketization. GeoJournal, vol. 79, no. 4, pp. 421-432.

Baldassare M., 1992. Suburban communities. Annual review of Sociology, vol. 18, no. 1, pp. 475-494.

BARANAUSKAItĖ A., 2015. Vilniaus miesto teritorijos elektorinès struktūros raida. VU Geografijos ir kraštotvarkos katedra, Vilnius: VU [Master thesis].

Baranauskaitë A., Buneika D., TuČas R., 2015. Elektoriniř struktürř erdvinë diferenciacija Lietuvos miestř regionuose. Geografijos metraštis, vol. 48, pp. 3-23.

BilodeaU A., 2009. Residential segregation and the electoral participation of immigrants in Australia. International Migration Review, vol. 43, no. 1, pp. 134-159.

BJøRKLUND T., 2007. The 1987 Norwegian local elections: A protest election with a swing to the right. Scandinavian Political Studies, vol. 11, no. 3, pp. 211-234.

Boren T., Gentile M., 2007. Metropolitan processes in post-communist states: An introduction. Geografiska Annaler, vol. 89, no. 2, pp. 95-110.

Brade I., Herfert G., Wiest K., 2009. Recent trends and future prospects of socio-spatial differentiation in urban regions of Central and Eastern Europe: A lull before the storm? Cities, vol. 26, no. 5, pp. 233-244. a clear political ideology associated with their social status.

\section{Acknowledgements}

The research was funded by a grant (agreement No. MIP 086/2014) from the Research Council of Lithuania.

Editors' note:

Unless otherwise stated, the sources of tables and figures are the authors', on the basis of their own research.

Burneika D., Daugirdas V., UbareVIČIENĖ R., 2014. Migration as a factor of development of the depopulating areas in East EU Countries - The case of Lithuania. Europa XXI , vol. 27, pp. 79-94.

Burneika D., UbareVIČIENĖ R., Valatka V., 2015. Socio-economic segregation in growing urban regions of Lithuania. Filosofija. Sociologija, vol. 26, no. 4, pp. 277-292.

BURNEIKA D.; UBAREVIČIENĖ R., 2016. Socio-ethnic segregation in the metropolitan areas of Lithuania. Czech Sociological Review, vol. 52, no. 6, pp. 795-81.

Burneika D., UbareVIČIené R., Valatka V., Baranauskaité A., Pociūté-Sereikiené G., Daugirdas V., Krupickaité D., 2017. Lietuvos metropoliniai regionai. Gyventoju erdvine diferenciacija XXI a. pradžioje. Vilnius: LSTC.

Central Electoral Commission of the Republic OF LITHUANIA, 2016. http://www.vrk.lt/en/home [5 March 2017].

ChandRa K., 2004. Why ethnic parties succeed: Patronage and ethnic head counts in India. New York: Cambridge University Press.

Charter of the New Urbanism, 1996. Congress for the New Urbanism, http://www.cnu.org/charter [10 March 2017].

Cohen C., Dawson M., 1993. Neighbourhood poverty and African American politics. American Political Science Review, vol. 87, no. 2, pp. 286-302.

CZzerniakiewicz J., CZerniakieWICZ M., 2007. Resettlements from the East 1944-1959. Warszawa: Wydawnictwo Wyżzzej Szkoły Pedagogicznej TWP. 
DAUKŠAS D., 2008. Pase jirašytoji tapatybè: Lietuvos lenku etninio/nacionalinio tapatumo trajektorijos. Lietuvos Etnologija: Socialines Antropologijos ir Etnologijos Studijo, vol. 8, pp. 57-72.

Eberhardt P., 2011. Political migrations on Polish territories (1939-1950). Warszawa: Instytut Geografii i Przestrzennego Zagospodarowania PAN.

DavoudI S., 2008. Conception of the city-region: A critical review. Urban Design and Planning, vol. 161, no. 2, pp. 51-60.

Erlingsson G.O., Persson M., 2011. The Swedish pirate party and the 2009 European Parliament Election: Protest or issue voting? Politics, vol. 31, no. 3, pp. 121-128.

EUROSTAT, 2015. Gini coefficient of equivalised disposable income. http://ec.europa.eu/eurostat/ [10 April 2017].

GaIDYS V., 2004. Viešoji nuomonè ir politika [in:] A. Krupavičius, A. Lukošaitis (eds.), Lietuvos politine sistema: sandara ir raida. Kaunas: Poligrafija ir Informatika.

GAIDYS V., 2014. Socialiniu demografiniu parametru jtaka gyventoju partinems preferencijoms ir politiniam aktyvumui: jungtiniu duomenu masyvy analize. Lietuvos gyventojai XXI a. pradžioje: Sociodemografiniai aspektai. Lietuvos socialinè raida, vol. 3, pp. 7-24.

GainsBorough J.F., 2001. Fenced off: The suburbanization of American politics. Washington: Georgetown University Press.

Gentile M., Tammaru T., van Kempen R., 2012. Heteropolitanization: Social and spatial change in Central and East European Cities. Cities, vol. 29, no. 5, pp. 291-350.

Gimpel J.G., Dyck J.J., ShaW D.R., 2004. Registrants, voters and turnout variability across neighborhoods. Political Behavior, vol. 26, no. 4, pp. 343-375.

Hall M., Crowder K.D., Tolnay S., 2010. Immigration and native residential mobility in established, new, and nongateway metropolitan destinations. Paper presented at the annual meeting of the Population Association of America, USA.

Hamilton F., Andrews K., Pichler-Milanovic N. (eds.), 2005. Transformation of cities in Central and Eastern Europe: Towards globalization. Tokyo: United Nations University Press.

HamnetT CH., 1996. Social geography: A reader. Arnold: London.
HieberT D., 2009. Segregation [in:] R. Johnston, G. Pratt, M. Watts, S. Whatmore (eds.), The Dictionary of Human Geography, (5th edition), pp. 673, Singapore: Wiley-Blackwell.

HUCKFELDT R., 1979. Political participation and the neighborhoods social context. American Journal of Political Science, vol. 23, no. 3, pp. 579-592.

Huckfeldt R., Sprague J., 1995. Citizens, politics and social communication. New York: Cambridge University Press.

International Labour Organisation, 2012. International standard classification of occupations, http://www.ilo.org/wcmsp5/groups/public/-dgreports/-dcomm/-publ/documents/publication/wcms_172572.pdf [2 April 2017].

Johnston R., PATtie C., 2006. Putting voters in their place. Geography and elections in Great Britain. Oxford: Oxford University Press.

JOHNSTON R.J., JONES K., 2010. Measuring segregation - cautionary tale. Environment and Planning, vol. 42, no. 6, pp. 1264-1270.

JuRkYnAS M., Ramonaitė A., 2005. Kaire ir dešiné Lietuvoje: eksperty ir elektorato nesusikalbejjimas. Lietuva po Seimo rinkimu, A. Jankauskas (ed.), Vilnius: Naujasis lankas, pp. 71-90.

Kaufmann K.M., 2004. The urban voter: Group conflict and mayoral voting behavior in American cities. The Politics of Race and Ethnicity, Ann Arbor: University of Michigan Press.

KRUPICKAITÉ D., 2011. Vilnius - between persistence and socio-spatial change. Europa regional, vol. 19, no. 3-4, pp. 21-31.

LEGEBY A., 2010. Urban segregation and urban form. From residential segregation to segregation in public space. Stockholm: KTH [licentiate thesis].

Leighley J.E., Vedutz A., 1999. Race, ethnicity and political participation: Competing models and contrasting explanations. Journal of Politics, vol. 61, no. 4, pp. 1092-1114.

Manis J.G.; StONE L.C., 1958. Suburban residence and political behaviour. The Public Opinion Quarterly, vol. 22, no. 4, 483-489.

Marcińczak S., Tammaru T., Novák J., Gentile M., Kovács Z., Temelová J., ValatKa V., Kährik A., SZABÓ B., 2015. Patterns of socioeconomic segregation in the capital cities of fast-track reforming postsocialist countries. Annals of the Association of American Geographers, vol. 105, no. 1, 183-202. 
MAsIULIS K., 1997. Lietuvos elitas: Ekonominess vertybess, politines orientacijos, prognozes. Studiju šaltiniai, 3. Vilnius: Pradai.

Massey D., Denton N., 1998. American apartheid: Segregation and the making of the underclass. Cambridge: Harvard University Press.

Mendelsohn E., 1983. The Jews of East Central Europe between the world wars. Bloomington: Indiana University Press.

Oliver J.E., Ha S.E., 2007. Vote choice in suburban elections. American Political Science Review, vol. 101, no. 3, pp. 393-408.

Park E., Burgess E., McKenzie R., 1925. The City: Suggestions for investigation of human behavior in the urban environment. University of Chicago Press: Chicago.

Parsons W., 2001. Viešoji politika: Politikos analizès teorijos ir praktikos jvadas. Vilnius: Eugrimas

Petrulis V., 2009. Lietuvos politinio lauko teritorine struktūra (elektorinio metodo pagrindu). Vilnius: $\mathrm{VU}$ [PhD thesis].

Ramonaité A., Jastramskis M., Kavaliauskaité J., NeVINSKAITÉ L., ŽIIIIUKAITĖ R., 2014. Kaip renkasi Lietuvos rinkejjai? Idejjos, interesai ir jvaizdžiai politikoje. Vilnius: Vilniaus universiteto leidykla.

RobInson T., NoriEga S., 2010. Voting migration as a source of electoral change in the Rocky Mountain West. Political Geography, vol. 29, no.1, pp. 28-39.

RudoKAITÉ J., 2014. Lietuvos Žiemgalos regiono elektorine struktūra, Vilnius: VU Geografijos ir kraštotvarkos katedra. Vilnius: VU [Master thesis].

SaviCKAIté I., KrupiCKaité D., TuČas R., 2013. Gyventoju rinkimines elgsenos kaita Vilniaus suburbanizacijos zonoje. Geografijos metraštis, vol. 46, pp. 72-94.

Scom A.J., 2001. Globalization and the rise of cityregions. European Planning Studies, vol. 9, no. 7, pp. 813-826.

Sellers J.M., Kubler D., Walter-Rogg M., WALKS A., 2013. The political ecology of the metropolis: Metropolitan sources of electoral behaviour in eleven countries. Colchester: ECPR Press.

SKLAR H., 2000. Booming economic inequality, falling voter turnout. March 1, 2000, Z Magazine, https://zcomm.org/zmagazine/booming-economic-inequality-falling-voter-turnout-by-site-administrator/ [22 May 2017].
StANILOV K., 2007. The post-socialist city: Urban form and space transformations in Central and Eastern Europe after socialism, Dordrecht: Springer.

StATISTICS LITHUANIA, 2016. http://osp.stat.gov.It/en/ web/guest/home [20 April 2017].

Stein R.M., Ulbig S.G., Post S.S., 2005. Voting for minority candidates in multiracial/multiethnic communities. Urban Affairs Review, vol. 41, no. 2, pp. 157-181.

Stokes S.C., Bolx C., 2009. The Oxford handbook of comparative politics. Oxford: Oxford University Press.

SÝKORA L., 2009. Post-socialist cities [in:] R. Kitchin, $\mathrm{N}$. Thrift (eds.), International encyclopedia of $\mathrm{Hu}-$ man Geography, pp. 387-395. Amsterdam-Oxford: Elsevier.

SzeLENYI I., 1996. Cities under socialism - and after [in:] G. Andrusz, M. Harloe, I. Szelenyi (eds.), Cities after socialism: Urban and regional change and conflicts in post-socialist societies, Oxford: Blackwell Publishers, pp. 286-317.

Tammaru T., Kulu H., 2003. The ethnic minorities of Estonia: Changing size, location, and composition. Eurasian Geography and Economics, vol. 44, no. 2, pp. 105-120.

Tammaru T., Marcińczak S., van Ham M., MusTERD S. (eds.), 2016. Socio-economic segregation in European capital cities: East meets West. London-New York: Routledge.

Terě̌KInAS A., Žıllys A., IndrILIŪNAité R., 2013. Pilietiškumas ir tapatumas šiuolaikineje visuomenèje: socialine atskirtis ir socialine segregacija Lietuvos didmiesčiuose. Vytauto Didžiojo universiteto mokslo klasteriai, vol. 2, pp. 171-185.

UbareVIČIEnĖ R., BurneiKa D., van Ham M., 2015. Ethno-political effects of suburbanization in the Vilnius Urban Region: An analysis of voting behavior. Journal of Baltic Studies, vol. 46, no. 1, pp. 1-26.

VAITEKŪNAS S., 2006. Lietuvos gyventojai per du tūkstantmečius. Mokslo ir enciklopediju leidybos institutas, Vilnius.

Valatka V., Burneika D., Ubarevičiené R., 2016. Large social inequalities and low levels of socioeconomic segregation in Vilnius [in:] T. Tammaru, S. Marcińczak, M. van Ham, S. Musterd (eds.), Socio-economic segregation in European Capital cities: East meets West, London-New York: Routledge, pp. 313-332. 
van Kempen R., Şule ÖzüEkren A., 1998. Ethnic segregation in cities: New forms and explanations in a dynamic world. Urban studies, vol. 35, no. 10, pp. 1631-1656.

WALKS R.A., 2005. City - suburban electoral polarization in Great Britain, 1950-2001. Transactions of the Institute of British Geographers, vol. 30, no. 4, pp. 500-517.

WaLks R.A., 2006. The cause of city - suburban political polarization? A Canadian case study. Annals of the Association of American Geographers, vol. 96, no. 2, pp. 390-414.

WHITE M.J., 1986. Segregation and diversity measures in population distribution. Population Index, vol. 52, no. 2, pp. 198-221.
Wolfinger R.E., 1965. The development and persistence of ethnic voting. The American Political Science Review, vol. 59, no. 4, pp. 896-908.

Wolfinger R.E.; Rosenstone S.J., 1980. Who votes? New Haven, CT: Yale University Press.

ZANINETTI J.M., 2009. Sustainable development in the USA. London: Wiley.

ŽılYS A., 2013. Rezidencine diferenciacija ir skirtumai Lietuvos moderniajame mieste:(po)sovietinis ar Vakary miestas? Kultūra ir visuomene. Socialinių tyrimų žurnalas, vol. 4, pp. 67-101.

ŽILYS A., 2015. Modernios visuomenès miesto pletra: Rezidencine diferenciacija Lietuvos didmiesčiuose. VDU: Kaunas [PhD thesis]. 